\title{
Isolation and Chemical Composition of Dinoflagellate Nuclei*
}

\author{
P. J. RIZZO $\dagger$ and L. D. NOODEN $\ddagger$
}

Department of Botany, University of Michigan, Ann Arbor, Michigan 48104

\begin{abstract}
SYNOPSIS. Nuclei were isolated from Peridinium cinctum. Peridinium trochoideum, Gyrodinium cohnii (Cryptothecodinium cohnii) and Gymnodinium nelsoni. The nuclei of $G$. cohnii, P. trochoideum and $G$. nelsoni were found to contain $\sim$ $6.9,34$ and 143 picograms of DNA respectively. The ratios to DNA of RNA, acid-soluble and acid-insoluble protein for $G$. cohnii were $0.32,0.13$ and 0.99 , respectively. The corresponding values for $P$. trochoideum were $0.22,0.08$ and 1.22 , while those for $G$. nelsoni were $0.21,0.10$ and 1.09 . The chemical composition of dinoflagellate nuclei is compared and contrasted with that of typical eukaryotic nuclei. The culture of these difficult organisms also is discussed.
\end{abstract}

Index Key Words: Peridinium cinctum; P. trochoideum; Gyrodinium cohnii; Gymnodinium nelsoni; culture; nuclear isolation; nuclear composition.

$\mathbf{B}^{\mathrm{E}}$ ECAUSE the nuclei of the dinoflagellate algae possess some special peculiarities [such as chromosomes remaining condensed throughout interphase $(9,19)]$ and their structure is considered intermediate between the prokaryotes and eukaryotes, they are of special interest. Since most of the previous work on these nuclei dealt with their ultrastructure or histochemical properties, it seemed important to isolate them and study their composition, especially in view of the remarkable observations from histochemical determinations that these chromosomes contained little or no protein $(9,19)$.

We have developed technics for preparing pure dinoflagellate nuclei in sufficient quantities to permit analyses of their chemical composition. Although several procedures for isolating nuclei from plants have been published, these were difficult to apply to dinoflagellate algae. The few papers dealing with the isolation of nuclei from plants have been discussed by Kuehl (20), and later by D'Alessio \& Trim (6). In general, these nuclear preparations are characterized by either relatively high yields and a low degree of purity, or a high degree of purity but low yields. Recently, a rapid method combining high yield and good purity has been described for the isolation of nuclei from pea seedlings (35), which represents a substantial improvement over pre-existing procedures. This procedure, however, requires a $14 \mathrm{hr}$ preincubation of the plant material in an infiltration medium. Tobacco leaf nuclei have recently been prepared with good yield and purity using procedures which employ a rapid cold-ether treatment to aid in the release of nuclei (14). A modification of this method was found to work very well for young leaves of etiolated soybeans (Rizzo, unpublished observations).

In the case of lower plants even fewer papers have been published on the isolation of nuclei, and almost all of them failed to include representative micrographs. There are no reports on the isolation of nuclei from an alga possessing a rigid cell wall and only a few reports concerning the isolation of nuclei from fungi $(1,10,11,21,31)$. Even in the case of lower plants lacking a rigid cell wall, the papers describing the isolation of nuclei are few $(12,24,28)$.

* This work was supported in part by an NIH predoctoral fellowship (5 FO1 GM43747-02) to PJR.

$\dagger$ Taken from a dissertation submitted by P. J. Rizzo to the graduate school of the University of Michigan in partial fulfillment of the requirements for the Ph.D. degree. Present address: Horticulture Department, Purdue University, Lafayette, Indiana 47907.

¥We thank Dr. Robert Helling for use of the sonicator, Dr. Sally Allen for use of the cream separator, Dr. Helen Gay for use of the Zeiss photomicroscope and Dr. Leigh Towill for helpful discussions.
The present study describes procedures for isolating nuclei from 4 species of dinoflagellates, 3 of which possess a rigid cell wall. Apart from the problems involved in purifying nuclei from plant cells in general, serious difficulties in breaking the cells without rupturing the nuclei, and in culturing these cells had to be surmounted. The nuclei from Gyrodinium cohnii and Peridinium trochoideum were used as the starting material for the preparation of chromatin, which will be described in subsequent papers. A preliminary report on chromatin and nuclei from $G$. cohnii has been published (30).

\section{MATERIALS AND METHODS}

\section{Culture Conditions}

While culture conditions have been developed for growing small quantities of dinoflagellates, it is difficult, in most cases, to grow them in the large quantities and higher densities needed for biochemical studies. Not surprisingly factors such as culture volume and flask shape often made a very big difference. There appeared to be a trend towards higher cell densities with higher surface to volume ratios. Since the conditions required differ somewhat for each species used, each is described separately.

Peridinium trochoideum.-Axenic cultures were kindly provided by Dr. R. R. Guillard, (Woods Hole Marine Biological Laboratory, Woods Hole, Massachusetts). Axenic stock cultures were maintained in $10 \mathrm{ml}$ of autoclaved half-strength medium "f" (13) (in $2 \times 15 \mathrm{~cm}$ tubes) at 20-22 C, under a light regime of $8 \mathrm{hr}$ dark, $16 \mathrm{hr}$ light, from fluorescent "CoolWhite" bulbs (Sylvania). All sea water (Marine Biological Laboratory, Woods Hole, Massachusetts), was filter sterilized with Whatman GF/C glass filters. The cultures were propagated axenically by a series of transfers to larger flasks ending with $2800 \mathrm{ml}$ "wide-mouth" Erlenmeyer flasks containing $2000 \mathrm{ml}$ of "pasteurized" Erdschreiber solution (33) or "pasteurized" half-strength medium " $\mathrm{f}$ " (13). These cultures were allowed to grow for 5-7 days (same growth conditions) before harvesting, at which time the cell density was about $1.5 \times 10^{4} \mathrm{cells} / \mathrm{ml}$ for the Erdschreiber solution and about $6 \times 10^{3}$ for halfstrength medium "f."

Peridinium cinctum.-Axenic cultures were purchased from the Culture Collection of Algae, Indiana University, Bloomington, Indiana. Stock cultures were maintained in $10 \mathrm{ml}$ of autoclaved 1336 medium (4) $(2 \times 15 \mathrm{~cm}$ tubes $)$ under the same growth conditions as $P$. trochoideum, and propagated by a similar series of transfers ending with $2000 \mathrm{ml}$ of autoclaved 1336 medium in $2800 \mathrm{ml}$ Erlenmeyer "wide-mouth" flasks. Addition of $50 \mathrm{ml}$ of autoclaved soil extract (33) gave a marked 
increase in growth rate and final cell density. Attempts were made to grow the cells in 5 gallon carboys under the same conditions, but very low cell densities were obtained.

Gymnodinium nelsoni.-An axenic culture was kindly provided by Dr. R. R. Guillard, Marine Biological Laboratory, Woods Hole, Massachusetts. Stock cultures were maintained in $10 \mathrm{ml}$ of autoclaved, half-strength medium " $\mathrm{f}$ " (13) (in $2 \times$ $15 \mathrm{~cm}$ tubes) at $23 \mathrm{C}$ under constant illumination from fluorescent "Cool-White" bulbs (Sylvania). All sea water (natural, from Marine Biological Laboratory, Woods Hole, Massachusetts) was sterilized by filtration through Whatman GF/C glass filters before use. Axenic cultures were transferred successively as described for $P$. trochoideum. The final cultures were allowed to grow for $\sim 1$ week, under the same conditions, after which the cell density was about $1-2 \times 10^{3}$ cells $/ \mathrm{ml}$.

Gyrodinium cohnii (Cryptothecodinium cohnii).-An axenic starter culture was a gift from Dr. G. G. Holz, Jr. (Department of Microbiology, State University of New York, Upstate Medical Center, Syracuse, N. Y.). Stock cultures were maintained in $5 \mathrm{ml}$ of AXM medium (29) under the same conditions described for Gymnodinium nelsoni except that no special provision was made to illuminate this alga since it is a nonphotosynthetic heterotroph. One stock culture, $(6 \mathrm{ml}$ in a 1.5 $\times 12 \mathrm{~cm}$ tube) containing $2-4 \times 10^{6}$ cells $/ \mathrm{ml}$, was used to inoculate 1 liter of modified AXM in a 5 liter Povitsky bottle. The modification consisted of a 10 -fold decrease in the amounts of glucose and acetate to reduce the accumulation of polysaccharides and lipids by these organisms. The cells were harvested after about $3 \frac{1}{2}$ days of growth at a density of about $10^{6} \mathrm{cells} / \mathrm{ml}$ (same conditions as the stock cultures).

\section{Isolation of Nuclei}

All steps following the initial harvest of the cells were carried out at 0-4 C. The procedure used for each species differs sufficiently to warrant individual description.

Peridinium trochoideum.-The cells were concentrated first in a DeLaval cream separator, then further by centrifugation at $2500 \mathrm{~g}$ for $10 \mathrm{~min}$. This pellet was suspended in isolation medium $\left[0.25\right.$ м sucrose, $5 \mathrm{~mm} \mathrm{CaCl}_{2}, 10 \%$ (w/v) Dextran 40] (24), buffered to a $\mathrm{pH}$ of 7.2 with $10 \mathrm{~mm}$ Tris-HCl, to give $1.5-2 \times 10^{6}$ cells $/ \mathrm{ml}$. Generally, the cells from 14-15 liters of culture were suspended in $120 \mathrm{ml}$ of isolation medium. These cells were disrupted by sonication in $30 \mathrm{ml}$ portions using a Biosonic II ultrasonicator (Bronwill Scientific, Rochester, N. Y.), each for a total of $2-3 \mathrm{~min}$ at $90 \%$ output. To reduce heating, the beakers were placed in an ice bath, sonicated for a maximum of $1 \mathrm{~min}$ and swirled for $30 \mathrm{sec}$ between sonications. This stage was very critical and had to be monitored carefully with a light microscope in order to assure maximal cell breakage and minimal nuclear disruption. The sonicate was then centrifuged at $3000 \mathrm{~g}$ for $10 \mathrm{~min}$ in a Sorvall SS-34 rotor. The pellet, containing nearly all of the intact nuclei, was suspended in $30 \mathrm{ml}$ of fresh isolation medium for layering on top of a 3-step discontinuous gradient consisting of the following per tube: $7 \mathrm{ml} 2.4$ м sucrose $+10 \%(\mathrm{w} / \mathrm{v})$ Dextran 10; $21 \mathrm{ml} 2.4 \mathrm{~m}$ sucrose; $16 \mathrm{ml} 2.2 \mathrm{~m}$ sucrose $+0.1 \%$ (v/v) Triton X-100 (Rohm and Haas, Philadelphia, Pennsylvania). All these solutions contained $10 \mathrm{~mm}$ Tris- $\mathrm{HCl}$ ( $\mathrm{pH}$ 7.2) and $5 \mathrm{~mm} \mathrm{CaCl}_{2}$. Ten $\mathrm{ml}$ of homogenate were layered over the gradient in each of 3 tubes and the upper $1 / 2$ of the $2.2 \mathrm{M}$ sucrose layer was stirred gently. The tubes were centrifuged at $27,000 \mathrm{~g}$ for $20 \mathrm{~min}$ in the Spinco SW 25.2 rotor. After centrifugation, the supernatant was decanted, and the insides of the tubes carefully wiped with a cotton swab to remove contaminating material. The nuclear pellet was gently suspended in isolation medium with a loose-fitting PotterElvehjem homogenizer and the previous centrifugation repeated. When necessary, the pellet suspension was filtered through a $25 \mu \mathrm{m}$ Nitex Nylon screen (Tolber, Ernst and Traber, Inc., Elmsford, New York), fitted to a stainless steel filtering pan (Baruch Instruments Corp., Ossining, New York) to remove cell fragments. Before filtering, the pellet was suspended in isolation medium with a loose-fitting Potter-Elvehjem glassTeflon homogenizer and diluted with 1-2 volumes of a buffer containing $0.14 \mathrm{M} \mathrm{NaCl}, 10 \mathrm{~mm}$ Tris-HCl ( $\mathrm{pH} \mathrm{7.6)}$ and $5 \mathrm{~mm}$ $\mathrm{MgCl}_{2}$. The final pellet was used for nuclear analysis or as the starting material for the preparation of chromatin.

Peridinium cinctum.-The cells were concentrated and disrupted exactly as described for $P$. trochoideum except that the suspension was sonicated for a total of $6-8 \mathrm{~min}$, and at maximum output. The nuclei were isolated as described for $P$. trochoideum except that the gradient consisted of $7 \mathrm{ml}$ of the sucrose-Dextran solution and $37 \mathrm{ml}$ of $2.4 \mathrm{M}$ sucrose. The upper $1 / 3$ of the $2.4 \mathrm{M}$ sucrose layer was gently stirred and the tubes were centrifuged at $9,780 \mathrm{~g}$ for $20 \mathrm{~min}$ in the Spinco SW 25.2 rotor. After removing the $2.4 \mathrm{~m}$ sucrose layer with a large-bore pipet, the nuclei were collected at the interface between the $2.4 \mathrm{M}$ sucrose and the sucrose-Dextran solution in the same manner.

Alternatively, the tubes were centrifuged at the same speed for $60 \mathrm{~min}$, and the nuclei were recovered in the pellet. This procedure gave higher yields of nuclei, but the preparations were badly contaminated with cell wall fragments. Most of the cell wall fragments, however, could be removed in the following manner. The nuclear pellet was suspended in $6 \mathrm{ml}$ of isolation medium and $2 \mathrm{ml}$ portions were gently layered over an equal volume of $2.4 \mathrm{M}$ sucrose plus $10 \%(\mathrm{w} / \mathrm{v})$ Dextran 10 in each of 3 tubes. Care was taken not to disturb the interface between the 2 solutions. After centrifugation at $18,000 \mathrm{~g}$ for $10 \mathrm{~min}$ in a Spinco SW 39 rotor, the nuclei banded on top of the sucrose-Dextran solution. Most cell wall fragments pelleted, while lighter debris was discarded with the supernatant. The nuclei were suspended in isolation medium and pelleted by centrifugation at $12,000 \mathrm{~g}$ for $10 \mathrm{~min}$ in the Sorvall SS-34 rotor. This final pellet constituted the purified nuclei.

Gymnodinium nelsoni.-The cells were concentrated by centrifugation at $650 \mathrm{~g}$ for $10 \mathrm{~min}$, and this pellet was suspended in $30-40 \mathrm{ml}$ of isolation medium (24) $\left(\mathrm{pH} \mathrm{7.2)}\right.$ at $\sim 2 \times 10^{5}$ cells $/ \mathrm{ml}$. The cells were sheared by hand with a Potter-Elvehjem glass-Teflon homogenizer until nearly all the cells were broken. The homogenate was sonicated for $7-10 \mathrm{sec}$ at maximum output with a Branson S-75 sonifer to remove adherent cytoplasm, then layered over $44 \mathrm{ml}$ of $2.2 \mathrm{M}$ sucrose $+0.1 \%(\mathrm{v} / \mathrm{v})$ Triton $\mathrm{X}-100$ in each of 3 tubes, the upper $1 / 3$ was gently stirred to form a partial gradient. After centrifugation at $9,780 \mathrm{~g}$ for $20 \mathrm{~min}$ in the Spinco SW 25.2 rotor, the sucrose was poured off and the insides of the tubes wiped with a cotton swab as described above.

The nuclear pellet was suspended in $5-8 \mathrm{ml}$ of isolation medium containing $0.5 \%(\mathrm{v} / \mathrm{v})$ Nonidet P-40 (Shell Oil Co.) and homogenized with 4-5 strokes using a Potter-Elvehjem glass homogenizing tube with a motor-driven Teflon pestle. This step removes the cytoplasmic tabs which still adhere to some of the nuclei. The nuclear homogenate was then centrifuged at $12,000 \mathrm{~g}$ for $10 \mathrm{~min}$ in the Sorvall SS-34 rotor to pellet the nuclei. The pellet was washed by suspending in $5-8 \mathrm{ml}$ of isolation medium using a Potter-Elvehjem glass Teflon homogenizer by hand, and the previous centrifugation 
was repeated. This final pellet was then used for nuclear analysis.

Gyrodinium cohnii.-Cells were concentrated by centrifugation at $2500 \mathrm{~g}$ for $5 \mathrm{~min}$, and the pellet was suspended in isolation medium which consisted of $0.25 \mathrm{M}$ sucrose, $5 \%(\mathrm{w} / \mathrm{v})$ Dextran 40, 2.5\% (w/v) Ficoll (Pharmacia), $5 \mathrm{~mm} \mathrm{CaCl}_{2}$ and $10 \mathrm{~mm}$ Tris-HCl ( $\mathrm{pH} \mathrm{7.2),} \mathrm{a} \mathrm{slight} \mathrm{modification} \mathrm{of} \mathrm{the}$ isolation medium of Honda et al. (16). The cells were disrupted by sonication as described for Peridinium trochoideum except that the suspension was sonicated for a total of $1-1 \frac{1}{2}$ min and at maximum output. Generally, the cells from 2 liters of culture (about $10^{6}$ cells $/ \mathrm{ml}$ ) were sonicated in $180 \mathrm{ml}$ of isolation medium $\left(1-1.5 \times 10^{7} \mathrm{cells} / \mathrm{ml}\right)$ and the suspension centrifuged at $480 \mathrm{~g}$ for $5 \mathrm{~min}$ to pellet the nuclei. The white bottom layer of the pellet contains "starch" grains, broken cell walls, some whole cells and some nuclei. The brown top layer contains most of the nuclei, whole cells and cellular debris. Several $\mathrm{ml}$ of fresh isolation medium was added to the pellet (composed of 2 layers). The top layer was carefully dislodged with a stirring rod, and the tube was gently "buzzed" with a vortex mixer. This step removed most of the material of greater density than nuclei, yet only a small percentage of nuclei were lost in the bottom layer. The nuclear suspensions were then combined and made up to a total volume of $30 \mathrm{ml}$ with isolation medium, which was layered over a 2-step discontinuous gradient consisting of the following: $7 \mathrm{ml}$ of $2.4 \mathrm{M}$ sucrose with $10 \%(\mathrm{w} / \mathrm{v})$ Dextran 10 , overlayered with $37 \mathrm{ml}$ of $2.2 \mathrm{M}$ sucrose containing $0.1 \%$ $(v / v)$ in Triton X-100. After layering the homogenate on top of this gradient $(10 \mathrm{ml} /$ tube), the upper $1 / 3$ of the $2.2 \mathrm{M}$ sucrose layer was stirred to form a partial gradient. The tubes were then centrifuged for $50 \mathrm{~min}$ at $48,000 \mathrm{~g}$. After centrifugation, the sucrose solutions were poured off and the insides of the tubes carefully wiped with a cotton swab as described. The nuclear pellet was gently suspended in $30 \mathrm{ml}$ of fresh isolation medium with a Potter-Elvehjem homogenizer and the previous centrifugation repeated. This final pellet was used for nuclear analysis or as the starting material for the preparation of chromatin.

\section{Light Microscopy of Isolated Nuclei}

All nuclear pellets were checked routinely for purity by staining with methyl green-pyronin $B$ and observing under the light microscope. With this stain, nuclei appear blue while nucleoli and cytoplasm are pink (18). The stain was also used to monitor cell breakage and to check the effectiveness of each step during development of the nuclear isolation procedure. All photomicrographs are of stained preparations and were taken with a Zeiss Photomicroscope.

\section{Counting of Whole Cells and Nuclei}

Nuclear counts were made using a hemocytometer. For $G$. cohnii and $G$. nelsoni, the nuclei had to be stained with methyl green-pyronin to improve visibility. Cell counts for $P$. trochoideum and $G$. cohnii also were made with a hemocytometer, while counts of $P$. cinctum and $G$. nelsoni cells were made using a Sedgewick-Rafter counting chamber.

\section{Chemical Determinations}

DNA and RNA were extracted by the method of Ogur \& Rosen (27). DNA was determined by the diphenylamine reaction of Burton (3), RNA by absorption at $260 \mathrm{~nm}$ (27), and protein by the method of Lowry et al. (23). Calf thymus or salmon sperm DNA (Sigma), purified yeast RNA (Sigma), and bovine serum albumin (Sigma) were used as standards. For the determination of protein, all samples (including the standard) were dissolved by heating at $80 \mathrm{C}$ for $10 \mathrm{~min}$ in $0.5 \mathrm{~N}$ or $1.0 \mathrm{~N} \mathrm{NaOH}$.

\section{Extraction of Acid-Soluble Proteins}

Nuclei were completely suspended in $1-2 \mathrm{ml}$ of cold $0.25 \mathrm{~N}$ $\mathrm{HCl}$ or $\mathrm{H}_{2} \mathrm{SO}_{4}$ and extracted for 20 min with intermittent shaking. The samples were centrifuged at $25,000 \mathrm{~g}$ for $15 \mathrm{~min}$, and the supernatant was removed with a Pasteur pipette. The pellet was extracted again as described above, and the combined supernatants were centrifuged to remove the small amount of particulate material that occasionally broke away from the $25,000 \mathrm{~g}$ pellet upon removal of the supernatant. The acidsoluble proteins were precipitated overnight with either 1 volume of $40 \%(\mathrm{w} / \mathrm{w})$ trichloroacetic acid (TCA) at $4 \mathrm{C}$, or 8 volumes of acetone at $-15 \mathrm{C}$. In both instances, the precipitate was collected by centrifugation at $25,000 \mathrm{~g}$ for $30 \mathrm{~min}$. The TCA precipitate was washed twice with $3-5 \mathrm{ml}$ of $80 \%(\mathrm{v} / \mathrm{v})$ ethanol, dispersing the pellet with a glass stirring rod and centrifuging as described above, for $15 \mathrm{~min}$. The acetone precipitate was dried in a desiccator under a partial vacuum.

\section{RESULTS}

Cell disruption.-A number of cell disruption methods developed for the isolation of nuclei from both plant and animal tissues were tested and found unsuitable for dinoflagellates with a cell wall. A Potter-Elvehjem homogenizer, expulsion through a syringe with various sized needles, a mortar and pestle with no abrasive or glass beads, and others did not rupture the cell wall. Freeze-thawing did not visibly affect the cell wall but did rupture the nuclear membrane. On the other hand, a Logemann Mill, a mortar and pestle with sand or in liquid nitrogen with no abrasive, a Parr Disruption Bomb, a Braun mechanical cell homogenizer, a French Press and others broke both cells and nuclei. A reasonable degree of success, however, was obtained using a French Press at low pressures with $P$. cinctum, an organism which proved to have exceptionally stable nuclei. The method which gave the best results was disruption by ultrasonication (described in Materials and Methods); however, exactly the right amount of sonication must be given here or the nuclear yield will be poor.

Isolation of nuclei.-Trial and error experiments with discontinuous sucrose gradients were run to determine empirically the best set of conditions for the isolation of nuclei from each of 4 species of dinoflagellates. The parameters varied were: (a) the number of sucrose layers; (b) sucrose molarity in the layers; (c) relative amounts of different sucrose layers; (d) additives to the sucrose solutions (detergents, high molecular weight polymers); (e) length and speed of centrifugation. Triton X-100 was included in the $2.2 \mathrm{M}$ sucrose solution, because of its ability to dissolve the outer nuclear membrane (17), to disperse mitochondria (25) and to lyse dinoflagellate chloroplasts (12). Dextran was included in the $2.4 \mathrm{M}$ sucrose solution to increase its density and viscosity since both the nuclei and the cell wall fragments sedimented through $2.4 \mathrm{M}$ sucrose easily. Supersaturated sucrose (34) was tested becausc of its high density and viscosity but was discontinued because the nuclei pelleted through this solution had a "ragged" appearance when examined by light microscopy. Better nuclear integrity with the sucrose-Dextran solution as compared to supersaturated sucrose may have been due to the lower osmotic strength of Dextran relative to a given density of sucrose. Possible deleterious effects of high concentrations of sucrose on 
isolated nuclei have previously been observed by Kuehl (20) and Løvtrup-Rein \& McEwen (22), and discussed recently by Tautvydas (35).

Peridinium cinctum nuclei.-Isolated nuclei from $P$. cinctum are shown in Fig. 1. The morphology of these nuclei is very different from that of the other 3 species, being bean-shaped rather than spheroid. Most nuclei are intact but several fragmented nuclei can be seen in the photograph. The only significant contaminants in these preparations are cell wall fragments which do not stain with methyl green-pyronin, suggesting that they contribute little as protein contaminants.

Work on this organism was terminated due to the slow growth rate of the culture, and no chemical characterization was performed on these nuclei. The nuclear isolation method was included here, because nuclei obtained were very good, and it will prove useful when better culture conditions become available. The addition of soil extract (33) may well provide a sufficient increase in growth rate and final cell density, but this was discovered too late to be used in this study. Peridinium cinctum is advantageous in that it is a fresh-water species, and thus does not require sea water. Another advantage is the large nucleus, which measures $\sim 10 \times 25 \mu \mathrm{m}$.

Peridinium trochoideum nuclei.-Figure 2 is a low-magnification light micrograph of $P$. trochoidium nuclei isolated as described in Materials and Methods. After the 27,000 $\mathrm{g}$ centriffugation, the cell homogenate is separated into 4 major zones. On top of the $2.2 \mathrm{M}$ sucrose layer is a zone composed mainly of cytoplasmic debris and whole cells. The interface between the 2.2 and $2.4 \mathrm{M}$ sucrose solutions contains mainly whole cells with some fragmented nuclei, cell wall fragments and cytoplasmic debris. Most of the cell wall fragments are trapped on top of the sucrose-Dextran solution; their shape may prevent most of them from penetrating this highly viscous solution. The spheroid nuclei form a pellet, and relatively few are trapped on top of this bottom layer. Very few whole cells are present in the nuclear pellet, and no cytoplasmic fragments can be detected using methyl green-pyronin stain. Some cell wall fragments are present in the nuclear pellet but can be removed by filtering the suspension through a $25 \mu \mathrm{m}$ Nitex Nylon screen (see Materials and Methods). This filtration step is seldom necessary, because the cell wall contamination is reduced to a negligible level after the second $27,000 \mathrm{~g}$ centrifugation. Frequently, only one such centrifugation is necessary.

A higher magnification of isolated Peridinium trochoideum nuclei is shown in Fig. 3. The nuclei are free of cytoplasmic tabs, and most of them have completely intact nuclear membranes. The ruptured nuclear membrane in the upper right portion of the photograph may have been caused by exposure to Triton X-100 in the $2.2 \mathrm{M}$ sucrose layer. The spheroid nuclei measure about $15 \mu \mathrm{m}$ in diameter, and the average yield of nuclei is about $16 \%$ of the original DNA. Higher yields of nuclei can be obtained by using less sonication, but this also increases the whole-cell contamination. It is worth mentioning here that isolated nuclei from all 4 species of dinoflagellates are indistinguishable from those in the cell with regard to overall morphology and methyl green-pyronin staining. Thus the possibility that a particular fraction of nuclei has been recovered in the pellet seems unlikely.

Gyrodinium cohnii nuclei.-Isolated nuclei from Gyrodinium cohnii are shown in Fig. 4. After the $48,000 \mathrm{~g}$ centrifugation, the cell homogenate is separated into 3 major zones. The pellet consists almost entirely of nuclei, with some "starch" grains and a few cell wall fragments; only cytoplasmic debris, whole cells, fragmented nuclei and cell walls are left in the upper layers. If the cells are not sufficiently disrupted, some whole cells will end up in the pellet. These can be removed by a filtration step as described for removing large cell wall fragments from $P$. trochoideum nuclei except that a $10 \mu \mathrm{m}$ screen is used. Usually the whole cell contamination is reduced to a negligible level by the 2nd $48,000 \mathrm{~g}$ centrifugation, and frequently only one such centrifugation is necessary.

As seen in Fig. 4, the nuclei are free of cytoplasmic tabs, and the nuclear membranes are intact. The nuclei measure about $5 \mu \mathrm{m}$ in diameter, and the average yield is about $14 \%$ of the original DNA.

Gymnodinium nelsoni nuclei.-Unlike the nuclei from $P$. cinctum, $P$. trochoideum, and $G$. cohnii, those from $G$. nelsoni had a tendency to clump under the conditions of isolation described. Using distilled water instead of the buffer containing $10 \mathrm{~mm}$ Tris and $5 \mathrm{~mm} \mathrm{CaCl}_{2}$ to make up the isolation medium did not prevent the clumping. The clumped nuclei are, however, easily dispersed by suspending the nuclear pellet in isolation medium with a motor-driven Potter-Elvehjem glass-Teflon homogenizer (Fig. 5).

After the cell breakage step, many nuclei still have varying amounts of cytoplasm adhering to them. A brief sonication removes nearly all these cytoplasmic tabs, with very little nuclear breakage. If the sonication step is omitted, the tabs remain attached to the nuclei after centrifugation, and homogenization in $0.5 \%(\mathrm{v} / \mathrm{v})$ Nonidet P-40 or Triton X-100 does not remove them entirely. Since this alga does not possess a cell wall, it is not necessary to centrifuge the nuclei through the $2.4 \mathrm{~m}$ sucrose-10\% ( $\mathrm{w} / \mathrm{v}$ ) Dextran solution. Whole cells and cytoplasmic debris do not pellet under the conditions employed; thus the final pellet consists entirely of nuclei, as can be seen from Fig. 5 . The isolated nuclei contain $\sim 70 \%$ of the DNA from the original cells. Nuclei isolated from $G$. nelsoni exhibited a large variation in size and shape (much greater than nuclei of other dinoflagellates), with diameters ranging from 10-40 $\mu \mathrm{m}$ (Fig. 5). Most of the nuclei measured 20-25 $\mu \mathrm{m}$ in diameter and were spheroid.

Interchromosomal material.-It has been suggested that the extrachromosomal matrix may be a factor in maintaining chromosomal integrity in dinoflagellates (5). This suggestion was based on the observation that treatment with trypsin for $2 \mathrm{hr}$ caused a breakdown of chromosomal integrity. The light micrograph shown in Fig. 6 indicates that dinoflagellate chromosomes maintain their morphology in the absence of the matrix material. One chromosome can be followed for its entire length. It seems likely then that the matrix is not responsible for maintaining chromosome structure in dinoflagellates. These chromosomes do disperse, however, when the nuclei are dissolved in $2 \mathrm{M} \mathrm{NaCl}$ or a buffer containing $1 \mathrm{~mm}$ EDTA and $10 \mathrm{~mm}$ Tris pH 8.

Chemical composition of dinoflagellate nuclei.-The amounts of DNA, RNA, acid-insoluble and acid-soluble protein per isolated nucleus from $P$. trochoideum, $G$. cohnii and $G$. nelsoni are given in Table 1, which is a quantitative comparison of these nuclear components. All values are expressed as picograms per nucleus, and represent the average of 5-8 separate determinations. The standard errors are given to the right of each value. It is apparent from Table 1 that there is a large difference in the amounts of DNA, RNA, and protein of the nucleus among the 3 dinoflagellates. This correlates well with the sizes of the 3 dinoflagellate nuclei. Since the orcinol test gave variable results with these nuclei (see p. 300, Ref. 8), RNA was determined by absorption at $260 \mathrm{~nm}$ and thus probably represents an overestimate $(7,26)$. 


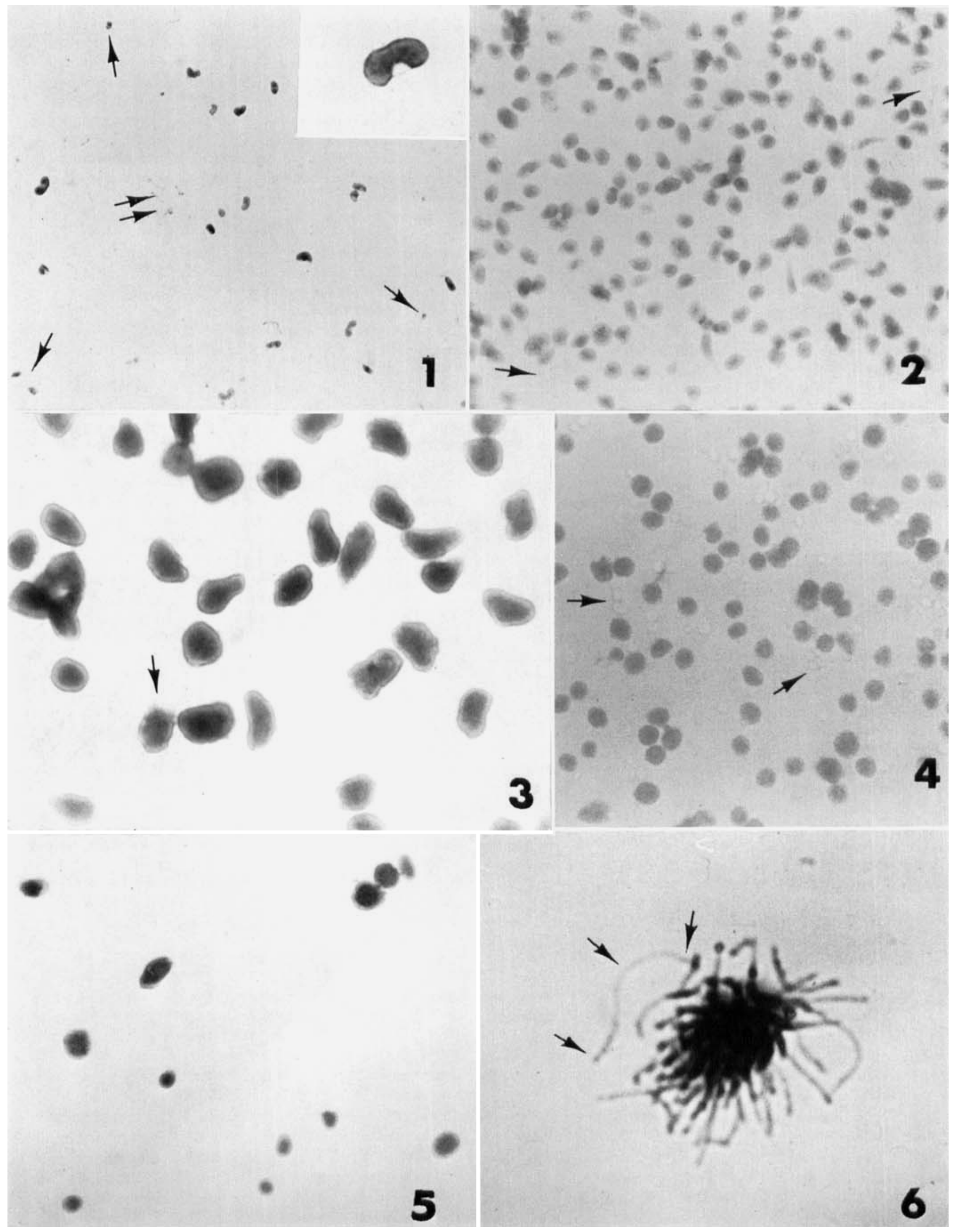


Isolation of Dinoflagellate Nuglei

TABLE 1. Comparison of the chemical composition per nucleus of 3 dinoflagellates.*

\begin{tabular}{lrrr}
\hline \hline & $\begin{array}{c}\text { Peridinium } \\
\text { trochoideum }\end{array}$ & $\begin{array}{c}\text { Gymnodinium } \\
\text { nelsoni }\end{array}$ & $\begin{array}{c}\text { Gyrodinium } \\
\text { cohnii }\end{array}$ \\
\hline DNA & $34.0 \pm 1.0$ & $143 \pm 4.9$ & $6.9 \pm 0.4$ \\
RNA & $7.5 \pm 0.7$ & $30 \pm 2.5$ & $2.2 \pm 0.1$ \\
$\begin{array}{l}\text { Acid-insoluble } \\
\text { protein }\end{array}$ & $41.0 \pm 0.6$ & $156 \pm 8.8$ & $6.8 \pm 0.4$ \\
$\begin{array}{l}\text { Acid-soluble } \\
\text { protein }\end{array}$ & $2.7 \pm 0.1$ & $14 \pm 2.2$ & $0.9 \pm 0.1$ \\
$\begin{array}{l}\text { Diameter }(\mu \mathrm{m}) \\
\text { niam }\end{array}$ & 15 & 25 & 5 \\
\hline
\end{tabular}

* All values expressed as picograms per nucleus.

Although the nuclei from the 3 dinoflagellates tested exhibit considerable differences in the absolute amounts of DNA, RNA, acid-insoluble and acid-soluble protein, the relative amounts of these components are quite similar for the 3 dinoflagellate nuclei. This is seen in Table 2, the values of which were calculated from the data given in Table 1. Table 2 also shows that the amount of acid-insoluble protein in the dinoflagellate nucleus is only slightly greater than the amount of DNA, while the amount of acid-soluble protein is only $\sim 10 \%$ of the amount of DNA. Both these values are much lower than that of typical cukaryotic nuclei.

\section{DISCUSSION}

The primary obstacle involved in isolating plant cell nuclei is the cell wall. It is not surprising that any disruption method that manages to break a rigid cell wall will almost surely rupture the nuclear membrane. In the case of the armored dinoflagellates, the cell wall poses a special problem. Even if the yield of intact nuclei from the disrupted cells were $100 \%$, the cell wall fragments would outnumber the nuclei. Since the cell wall fragments are similar in density to the nuclei, difficulty is encountered in separating them by differential or gradient centrifugation. In this respect there is an advantage in working with a multicellular rather than a uni-

TABLE 2. Comparison of the relative amounts of $D N A, R N A$, acid-insoluble and acid-soluble protein of nuclei from 3 dinoflagellates.*

\begin{tabular}{lcccc}
\hline \hline & $\begin{array}{c}\text { Acid- } \\
\text { insoluble }\end{array}$ & $\begin{array}{c}\text { Acid- } \\
\text { soluble } \\
\text { Protein/ } \\
\text { DNA }\end{array}$ & $\begin{array}{c}\text { Total } \\
\text { Protein/DNA }\end{array}$ \\
\hline $\begin{array}{l}\text { Organism RNA/DNA } \\
\text { Peridinium }\end{array}$ & 0.22 & 1.22 & 0.08 & 1.30 \\
$\begin{array}{l}\text { trochoideum } \\
\begin{array}{l}\text { Gyrodinium } \\
\text { cohnii }\end{array}\end{array}$ & 0.32 & 0.99 & 0.13 & 1.12 \\
$\begin{array}{l}\text { Gymnodinium } \\
\text { nelsoni }\end{array}$ & 0.21 & 1.09 & 0.10 & 1.19
\end{tabular}

* Ratios calculated from averages given in Table 1.
TABLE 3. DNA content of some representative plant nuclei.

\begin{tabular}{lcc}
\hline Organism & $\begin{array}{c}\text { DNA/Nucleus } \\
\text { (picograms) }\end{array}$ & Reference \\
\hline Higher plants: & & \\
Lupinus albus (2N) & 5 & 15 \\
Zea mays (2N) & 11 & 15 \\
Vicia faba (2N) & 90 & 15 \\
Lilium longiflorum (2N) & 120 & 15 \\
Lower plants: & & \\
Saccharomyces cerevisiae (2N) & 0.046 & 1 \\
Chlorella* (N) & 0.066 & 32 \\
Neurospora crassa (N) & 0.05 & 15 \\
Euglena gracilis (N) & 3 & 28 \\
Gyrodinium cohnii & 6.9 & Present study \\
Peridinium trochoideum & 34 & Present study \\
Gymnodinium nelsoni & 143 & Present study
\end{tabular}

* Determined for whole cells instead of isolated nuclei.

cellular plant. In the former, much of the cell wall debris, because of its fibrous nature, can be removed by a filtration step through Miracloth or cheesecloth. Many of the cell wall fragments from armored dinoflagellates are broken into sections which are too similar to the nuclei in size to allow adequate separation without a tremendous reduction in yield, and these fragments cannot be filtered out with Miracloth or cheesecloth. However, filtration through small pore Nitex Nylon screens can be used with some success with dinoflagellates as described under Results.

In contrast to most of the present methods for the isolation of plant nuclei, the procedures described here combine good yield and high purity without the use of long preincubations of cell wall-digesting enzymes. An important disadvantage of these lengthy treatments is the possibility that changes occur in the nuclei during incubation.

In the present study, sonication was found to be the only satisfactory means for breaking the cell walls without breaking the nuclei. This method of cell disruption may prove useful for isolating nuclei from other types of algae with rigid cell walls. Also, the combination of Dextran and $2.4 \mathrm{M}$ sucrose to give a solution of very high viscosity made it possible to separate the majority of the cell wall fragments from the nuclei by centrifugation. This solution may be helpful in isolating nuclei from unicellular algae in general. By varying the length and speed of centrifugation, a balance can be reached in which cellular components as dense as or denser than the nuclei can be removed. This may be done by pelleting the nuclei and not the contaminating material as in the case of $G$. cohnii and $P$. trochoideum, or by pelleting the contaminating material and not the nuclei as in the case of $P$. cinctum.

A comparison of the DNA content of dinoflagellate nuclei with various other plant nuclei is given in Table 3 . The main

Figs. 1-6. [Dinoflagellate nuclei, stained with methyl green-pyronin.] 1. Light micrograph of isolated Peridinium cinctum nuclei Some fragmented nuclei (single arrow) and cell wall fragments (double arrows) are present. $\times 160$. Inset, $\times 540$. 2. Low-magnification light micrograph of isolated Peridinium trochoideum nuclei. A few cell wall fragments (arrows) are present. $X 230$. 3 . High-magnification light micrograph of isolated Peridinium trochoideum nuclei. A ruptured membrane (arrow) of one of the nuclei can be seen. $\times 600$. 4. Light micrograph of Gyrodinium cohnii nuclei. Some starch grains (arrows) are present. $\times 800$. 5. Light micrograph of Gymnodinium nelsoni nuclei. $\times 250$. 6. Isolated Peridinium trochoideum nucleus with completely disrupted nuclear membrane. One chromosome (arrows) can be followed for its entire length. $\times 1800$. 
point to be drawn from this table is that the amount of DNA in the dinoflagellate nucleus is unusually high for a unicellular organism and rivals that of higher plant nuclei. Repeated sequences are reported to be present in $G$. cohnii, but no estimate has been given of the relative proportions of unique and repeated sequences (2).

Nuclei from $G$. nelsoni have been isolated previously by Mendiola et al. (24), and some of their data are in disagreement with those reported here. First of all, the absolute amounts of DNA, RNA and protein per isolated nucleus reported by Mendiola et al. were 1100, 160 and 1000 picograms respectively, which is a systematic difference, $\sim 10$ times higher than the respective values shown in Table $1(146,30$ and 170 picograms). Since the same strain of G. nelsoni was used in both studies, it is unlikely that our cultures differed in their nuclear DNA, RNA and protein content. As a check of our methods, the procedure used for nuclear DNA determinations in the present study (see Materials and Methods) was also used to determine the DNA content of higher plant (Zea mays) nuclei. Since values obtained were in agreement with literature values, our procedures are reliable. Moreover, the DNA contents for $Z$. mays and $G$. cohnii bear approximately the same relationship to one another as their volumes, which further indicates that our determinations are accurate.

The amount of DNA per nucleus reported in the present study is very high for these simple organisms, and this suggests that they may be polyploid or contain a substantial amount of redundant DNA. While the DNA content of the dinoflagellate nuclei studied is remarkably high, the amount of acidsoluble protein, which would include histones if present, is very low, especially when viewed relative to DNA.

Finally, it should be noted that while a naked dinoflagellate such as $G$. nelsoni offers a definite advantage in that high yields of nuclei are easily obtained, these organisms are difficult to culture and neither divide rapidly nor grow to high densities. Therefore, G. cohnii and $P$. trochoideum are at present more suitable organisms for studies which require large amounts of material. If the culturing of naked dinoflagellates such as $G$. nelsoni and zooxanthellae could be improved, these organisms would be excellent material for the study of dinoflagellate nuclei and chromatin.

\section{REFERENCES}

1. Bhargava, M. M. \& Halvorson, H. O. 1971. Isolation of nuclei from yeast. J. Cell Biol. 49, 423-9.

2. Britten, R. J. \& Kohne, D. E. 1968. Repeated sequences in DNA. Science 161, 529-40.

3. Burton, K. 1956. A study of the conditions and mechanism of the diphenylamine reaction for the colorimetric estimation of deoxyribonucleic acid. Biochem. J. 62, 315-22.

4. Carefoot, J. R. 1968. Culture and heterotrophy of the freshwater dinoflagellate Peridinium cinctum FA. ovoplanum Lindeman. J. Phycol. 4, 129-31.

5. Chunosoff, L. \& Hirchfield, H. 1967. Nuclear structure and mitosis in the dinoflagellate Gonyaulax monilata. J. Protozool. 14, $157-63$.

6. D'Alessio, G. \& Trim, A. R. 1968. A method for the isolation of nuclei from leaves. J. Exp. Bot. 19, 831-9.

7. de Deken-Grenson, M. \& de Deken, R. H. 1959. Elimination of substances interfering with nucleic acid estimation. Biochim. Biophys. Acta 31, 195-207.

8. Dische, Z. 1955. Color reactions of nucleic acids and their constituents based on reactions of their sugars, in Chargaff, E. \&
Davidson, J. N., eds., The Nucleic Acids. Academic Press, New York, 1, 285-305.

9. Dodge, J. D. 1966. The Dinophyceae, in Godward, M. B. E., ed., The Chromosomes of the Algae. Edward Arnold, New York, 96-115.

10. Duffus, J. M. 1969. The isolation of nuclei from the yeast Schizosaccharomyces pombe. Biochim. Biophys. Acta 195, 230-3. 11. Dwivedi, R. S., Dutta, S. K. \& Bloch, D. P. 1969. Isolation and characterization of chromatin from Neurospora crassa. J. Cell Biol. 43, 51-8.

12. Franker, C. K. 1970. Some properties of DNA from zooxanthellae harbored by an anemone Anthopleura elegantissima. J. Phycol. 6, 299-306.

13. Guillard, R. R. L. \& Ryther, J. H. 1962. Studies on marine planktonic diatoms I. Cyclotella nana Hustedt and Detonula confervaca (Gleve) Gran. Can. J. Microbiol. 8, 229-39.

14. Hamilton, R. H., Kunsch, U. \& Temperli, A. 1972. Simple rapid procedures for isolation of tobacco leaf nuclei. Anal. Biochem. 49, 48-57.

15. Holliday, R. 1970. The organization of DNA in eukaryotic chromosomes. Symp. Soc. Gen. Microbiol. 20, 359-80.

16. Honda, S. I., Hongladarom, T. \& Laties, G. G. 1966. A new isolation medium for plant organelles. J. Exp. Bot. 17, 460-72.

17. Hymer, W. C. \& Kuff, E. L. 1964. Isolation of nuclei from mammalian tissues through the use of Triton X-100. J. Histochem. Cytochem. 12, 359-63.

18. Jensen, W. A. 1962. Botanical Histochemistry. Freeman, San Francisco.

19. Kubai, D. F. \& Ris, H. 1970. Chromosome structure. Ann. Rev. Genetics 4, 263-94.

20. Kuehl, L. 1964. Isolation of plant nuclei. Z. Naturforsch. $19 \mathrm{~b}, 525-32$.

21. Leighton, T. J., Dill, B. C., Stock, J. J. \& Phillips, C. 1971. Absence of histones from the chromosomal proteins of fungi. Proc. Nat. Acad. Sci. U.S. 68, 677-80.

22. Løvtrup-Rein, H. \& McEwen, B. S. 1966. Isolation and fractionation of rat brain nuclei. J. Cell Biol. 30, 405-15.

23. Lowry, O. H., Rosenbrough, J. N., Farr, A. L. \& Randall, R. J. 1951. Protein measurement with the Folin phenol reagent. J. Biol. Chem. 193, 265-75.

24. Mendiola, L. R., Price, C. A. \& Guillard, R. R. L. 1966. Isolation of nuclei from a marine dinoflagellate. Science 153, 1661-3.

25. Mitchell, P. \& Moyle, J. 1967. Proton-transport phosphorylation, in Slater, E. C., Kaniuga, Z. \& Wojtezak, L., eds., Biochemistry of Mitochondria. Academic Press, New York, 66-81.

26. Munro, H. N. \& Fleck, A. 1966. The determination of nucleic acids, in Glick, D. ed., Methods of Biochemical Analysis. Interscience, New York, 14, 113-76.

27. Ogur, M. \& Rosen, G. 1950. The nucleic acids of plant tissues. I. The extraction and estimation of desoxypentose nucleic acid and pentose nucleic acid. Arch. Biochem. 25, 262-76.

28. Parenti, F., Brawerman, G., Preston, J. F. \& Eisenstadt, J. M. 1967. Isolation of nuclei from Euglena gracilis. Biochim. Biophys. Acta 195, 234-43.

29. Provasoli, L. \& Gold, K. 1962. Nutrition of the American strain of Gyrodinium cohnii. Arch. Mikrobiol. 42, 196-203.

30. Rizzo, P. J. \& Noodén, L. D. 1972. Chromosomal proteins in the dinoflagellate alga Gyrodinium cohnii. Science 176, 796-7.

31. Rozijn, Th. H. \& Tonino, G. J. M. 1964. Studies on the yeast nucleus. I. The isolation of nuclei. Biochim. Biophys. Acta 91, 105-12.

32. Sitz, T. O., Kent, A. B., Hopkins, H. A. \& Schmidt, R. R. 1970. Equilibrium density-gradient procedure for selection of synchronous cells from asynchronous cultures. Science 168, 1231-2.

33. Starr, R. C. 1964. The culture collection of algae at Indiana University. Am. J. Bot. 51, 1013-44.

34. Stern, H. 1967. Isolation and purification of plant nucleic acids from whole tissues and from isolated nuclei, in Grossman, P. \& Moldave, K., eds., Methods in Enzymology, Academic Press, New York, 12B, 100-12.

35. Tautvydas, K. J. 1971. Mass isolation of pea nuclei. Plant Physiol. 47, 499-503. 